(Fakul tas Kesehatan Universi tas Muhammadiyah Gresik)

\title{
Peningkatan Lansia Sehat Dan Bahagia Di Panti WERDHA HARGO DEDALI
}

\author{
Widiharti*1 ${ }^{*}$, Wiwik W' ${ }^{2}$, Lidia A ${ }^{3}$ Yusrohul $^{3}$, Kamelia ${ }^{4}$ \\ 1,2,3 Dosen Profesi Ners; Fakultas Kesehatan; Universitass Muhammadiyah Gresik; Jl. Proklamasi No 54 Gresik \\ ${ }^{4,5}$ Mahasiswa Profesi Ners; Fakultas Kesehatan; Universitass Muhammadiyah Gresik; Jl. Proklamasi No 54 Gresik \\ widiharti.@umg.ac.i
}

\begin{abstract}
Abstrak
Proses penuaan merupakan suatu proses alamiah yang tidak dapat dicegah dan merupakan hal yang wajar. Proses menua tetap menimbulkan permasalahan baik secara fisik, biologi mental maupun sosial. Depresi pada lanjut usia menjadi masalah utama. Lansia di Panti Tresna Werdha Hargo Dedali sebanyak 43 orang. Tujuan pengabdian masyarakat ini untuk meningkatkan lansia sehat dan bahagia serta mencegah depresi pada usia lanjut.

Metode yang digunakan yaitu 1) memberikan pendidikan kesehatan, 2) latihan fisik dan senam dilakukan 3 kali selama 2 minggu, 3) terapi Aktivitas Kelompok dengan teka teki silang, cerdas cermat dan tebak gambar. Setelah itu mengukur tingkat depresi lansia instrument yang digunakan Inventaris Depresi Beck (IDB). Analisis yang digunakan yaitu univariat. Pelaksanaan penngabdian masyarakat ini dilakukan pada 23 September - 5 Oktober 2019. Besar sampel 43 lansia

Tingkat depresi lansia sebagian besar normal 62,5\%, aspek kognitif mental lansia sebagian besar mengalami kerusakan fungsi mental ringan sebanyak 37,5\%, kerusakan intelektual sedang 27,5\%.

Dari hasil kegiatan pengabdian masyarakat sudah banyak lansia yang memahami tentang kegiatan untuk mengurangi tingkat depresi lansia dan turut serta pelaksanaan kegiatan derajat kesehatan dan tingkat depresi lansia juga dalam nilai normal, kegiatan yang telah dilakukan secara rutin oleh Panti Werda Hargo Dedali berdampak positif pada lansia.
\end{abstract}

Kata kunci; Lansia, Depresi

\begin{abstract}
Until now, the number of residents in the orphanage recorded in the management's data is 43 people. Hargo Dedali's Home for the Tresna Werdha also runs a support system for the elderly who live in or outside the institution (in the form of clothing, health, and religious counseling) to achieve social welfare. The purpose of community service is to increase healthy and happy elderly.

The method used is to provide health education, conduct activities such as gymnastics, quizzes. Measuring the level of depression in the elderly with a depression level instrument

Elderly depression rates are mostly normal $62.5 \%$, cognitive aspects of mental elderly mostly experience mild mental function damage as much as $37.5 \%$, moderate intellectual damage $27.5 \%$.

From the results of community service activities, there are many elderly people who understand activities to reduce the level of depression in the elderly and participate in the implementation of health status activities and the level of depression in the elderly are also in normal values, activities that have been carried out routinely by the Werda Hargo Dedali Home have a positive impact on the elderly
\end{abstract}




\section{PENDAHULUAN}

Panti Tresna Werdha Hargo Dedali Surabaya didirikan pada tanggal 30 Januari 1987 oleh sosok pejuang wanita 45 Jawa Timur dan diprakarsai oleh almarhumah ibu R. Soedarijah Soerodikoesoemo (Dar Mortir). Latar belakang berdirinya panti ini bermula dari rasa keprihatinan ibu Dar Mortir yang melihat banyaknya perempuan veteran seperjuangan yang menjanda dan keadaannya perlu dibantu, di samping karena tidak memiliki tempat tinggal (tuna wisma) juga sebagai wujud penghargaan atas jasa-jasa mereka yang telah memperjuangkan dan membela NKRI. Sehingga berangkat dari keprihatinan itu kemudian ibu Dar Mortir menyampaikan ke teman-temannya untuk mendirikan sebuah yayasan sosial yang kemudian diberi nama Yayasan Panti Tresna Werdha Hargo Dedali.

Tujuan pendirian Panti Tresna Werdha Hargo Dedali Surabaya, yaitu untuk mewadahi para veteran wanita pejuang 45 , namun seiring berjalannya waktu populasi dari para pejuang tersebut makin berkurang, sehingga pada akhirnya pengurus Panti Tresna Werdha Hargo Dedali memutuskan untuk menerima lansia dari masyarakat umum yang membutuhkan, khususnya para wanita yang berusia 60 tahun dan tidak sedang dalam keadaan sakit sebagaimana syarat dan ketentuan dari Departeman Sosial saat itu.
Proses penuaan merupakan suatu proses alamiah yang tidak dapat dicegah dan merupakan hal yang wajar. Proses menua tetap menimbulkan permasalahan baik secara fisik, biologi mental maupun social [2]. Depresi pada lanjut usia menjadi masalah utama. Depresi merupakan salah satu ganguan kesehatan mental yang sering ditemui pada lanjut usia. Depresi pada lansia berbeda dengan depresi pada pasien yang lebih muda karena gejala - gejala depresi sering berbaur dengan keluhan somatik [1]. Faktor resiko depresi pada lansia lebih banyak diderita oleh wanita daripada pria, lansia yang memiliki status kesehatan buruk, penyakit somatic $^{[3]}$. Tujuan pengabdian masyarakat ini untuk meningkatkan lansia sehat dan bahagia

\section{METODE}

Sasaran kegiatan pengabdian masyarakat ini adalah para lansia yang ada di Panti Tresna Werdha Hargo Dedali, yang berjumlah 43 Lansia. Metode yang digunakan yaitu 1) memberikan pendidikan kesehatan, 2) latihan fisik dan senam dilakukan 3 kali selama 2 minggu, 3) terapi Aktivitas Kelompok dengan teka teki silang, cerdas cermat dan tebak gambar. Setelah itu mengukur tingkat depresi lansia instrument yang digunakan Inventaris Depresi Beck (IDB). Analisis yang digunakan yaitu 
univariat. Pelaksanaan pengabdian masyarakat ini dilakukan pada 23 September - 5 Oktober 2019 di Panti Tresna Werdha Hargo Dedali. Besar sampel 43 lansia

\section{HASIL DAN PEMBAHASAN}

\section{Karakteristik Lansia}

Tabel 1 Distribusi Frekuensi Berdasarkan Umur, Tingkat pendidikan, agama Lansia Di Panti Tresna Werdha Hargo Dedali

\begin{tabular}{|c|c|c|c|}
\hline No & Kategori & Frekuensi & Persentase \\
\hline \multicolumn{4}{|c|}{ Usia } \\
\hline 1. & $45-59$ tahun & 0 & 0 \\
\hline 2. & $60-74$ tahun & 16 & 40 \\
\hline 3. & $75-90$ tahun & 21 & 52,5 \\
\hline \multirow[t]{2}{*}{4.} & $>90$ & 3 & 7,5 \\
\hline & Jumlah & 40 & $100 \%$ \\
\hline \multicolumn{4}{|c|}{ Pendidikan } \\
\hline 1. & Tidak Sekolah & 3 & 7,5 \\
\hline 2. & SD & 16 & 40 \\
\hline 3. & SMP & 11 & 27,5 \\
\hline 4. & SMA & 7 & 17,5 \\
\hline 6. & S1 & 2 & 5 \\
\hline 7. & S2 & 1 & 2,5 \\
\hline & Jumlah & 40 & $100 \%$ \\
\hline \multicolumn{4}{|c|}{ Agama } \\
\hline 1. & Islam & 24 & 60 \\
\hline 2. & Kristen & 7 & 17,5 \\
\hline 3. & Katolik & 2 & 5 \\
\hline 4. & Konghucu & 3 & 7,5 \\
\hline 5. & Budha & 2 & 5 \\
\hline 6. & Protestan & 2 & 5 \\
\hline & Jumlah & 40 & $100 \%$ \\
\hline
\end{tabular}

2. Pengkajian Depresi dengan Menggunakan Depresi IDB

Tabel 2 Distribusi Frekuensi Pengkajian Depresi dengan Menggunakan IDB pada Lansia di Panti Tresna Werdha Hargo Dedali

No Kategori Jumlah Presentasi

\begin{tabular}{llcc}
\hline 1 & Normal / tidak ada & 25 & 62,5 \\
2 & Depresi ringan & 7 & 17,5 \\
3 & Depresi sedang & 1 & 2,5 \\
4 & Depresi berat & 7 & 17,5 \\
\hline & Jumlah & $\mathbf{4 0}$ & $\mathbf{1 0 0 \%}$ \\
\hline
\end{tabular}

Berdasarkan tabel 2 hasil tingkat depresi lansia sebagian besar normal 62,5\%, aspek kognitif mental lansia sebagian besar mengalami kerusakan fungsi mental ringan sebanyak $37,5 \%$, kerusakan intelektual sedang 27,5\%.

Hasil depresi lansia di panti tresna werdha hargo dedali sebagian besar normal berbeda dengan tingkat depresi lansia yang ada di binaan klinik prima medika sebelum dilakukan peer group pada lansia. Hal ini bisa disebabkan karena lingkungan atau komunitas yang sama akan mempengaruhi psikologis lansia ${ }^{[6]}$. Dimana lansia yang berada di bawa binaan klinik medika sebagian besar tinggal bersama keluarga sehingga tingkat depresi lansia tinggi hal bisa disebabkan karena lansia yang tinggal bersama keluarganya tidak menuntut kemungkinan mengalami masalah keluarga.

Tingkat intelektual lansia sebagian besar sedang, hal ini sebagian besar usia lansia sudah termasuk golongan old sebanyak 21 orang lansia. Kegiatan yang dilakukan untuk mempertahankan intelektual lansia telah dilakukan aktivitas yang terkait aspek intelektual salah satu kegiatan yang kami lakukan yaitu teka-teki silang untuk membantu lansia menstimulasi kognitif dan psikomotor. Stimulus sensori dengan music dapat berfungsi sebagai ungkapan perhatian, 
kualitas dari music yang memiliki andil terhadap fungsi - fungsi dalam pengungkapan perhatian [5], [7]. Selain itu juga untuk menjalin hubungan kerukunan terhadap sesama lansia yang ada di Panti Tresna Werdha Hargo Dedali Surabaya. Kegiatan tersebut dapat membuat mereka menjadi bahagia.

\section{KESIMPULAN}

Dari hasil kegiatan pengabdian masyarakat sudah banyak lansia yang memahami tentang kegiatan untuk mengurangi tingkat depresi lansia dan turut serta pelaksanaan kegiatan derajat kesehatan dan tingkat depresi lansia juga dalam nilai normal, kegiatan yang telah dilakukan secara rutin oleh Panti Werda Hargo Dedali berdampak positif pada lansia.

\section{SARAN}

Pengabdian masyarakat ini sebelumnya juga dilakukan pada komunitas lansia yang di untuk mengukur tingkat depresi sebelum dan sesudah diberikan tindakan, untuk selanjutnya perlu dilakukan pada lansia yang ada di masyarakat

\section{DAFTAR PUSTAKA}

[1] w. Widiyawati and D. J. E. Sari, Keperawatan Gerontik, Malang: literasi nusantara, 2020.

[2] Kozier, Buku Ajar Fundamental Keperawatan Konsep, proses \& praktik, Jakarta: EGC, 2010.

[3] D. Novi Herawati, "Hubungan Karakteristik Dengan Kejadian Depresi Pada lansia," Jurnal Keperawatan Jiwa, vol. 7, pp. 189-190, 2019.
[4] C. B. Rosdahl, Buku Ajar Keperawatan Dasar, Jakarta: EGC, 2014.

[5] N. M. R. T. H. Mia Fatma Eka Sari, Meningkatkan Kualitas Hidup Lansia Konsep dan Berbagi Intervensi, Malang: Wieneka Media, 2018.

[6] K. Pae, "Perbedaan Tingkat Depresi Pada Lansia di Panti Werdha dan yang Tinggal Di Rumah Bersama Keluarga," Jurnal ners LENTERA, vol. Vol 5 No 1, pp. 21-32, 2017.

[7] Pertiwi, "Hubungan tekanan darah dengan tingkat kecemassan pada lansia santa angela di samarinda," Media sains, pp. 21-27, 2017. 